International Journal of Business and Management Review

Vol.10, No.1, pp.25-43, 2022

Print ISSN: 2052-6393(Print),

Online ISSN: 2052-6407(Online)

\title{
FINANCIAL GAP AND SUSTAINABLE GOVERNMENT FINANCIAL INTERVENTIONS TO SMALL AND MEDIUM SCALE ENTERPRISES IN NIGERIA: DEVELOPING A SUSTAINABLE FRAMEWORK
}

\author{
Adegoke1, J. F. PhD, Nwankpa $^{2}$, N.N. PhD, Bakare ${ }^{3}$, L. A³ PhD, Tijani ${ }^{4}$, S. A. \& Zubair ${ }^{5}$, O. J. \\ Department of Business Administration and Management ${ }^{1,2,4,5}$ \\ Federal Polytechnic, Ede, Osun State; \\ Department of Public Administration and Political Science, \\ Fountain University, Osogbo, Osun State ${ }^{3}$.
}

\begin{abstract}
J. F. Adegoke, N.N. Nwankpa, L. A. Bakare, S. A. Tijani, and O. J. Zubair (2022) Financial Gap and Sustainable Government Financial Interventions to Small and Medium Scale Enterprises in Nigeria: Developing a Sustainable Framework, International Journal of Business and Management Review, Vol.10, No.1, pp.25-43
\end{abstract}

\begin{abstract}
The Nigerian government, having considered the oil price volatility and the need to address its high reliance of its budget on oil, by diversifying the economy, has embarked on a series of programmes and reforms to boost non-oil sector of the economy, most importantly, the SME subsector. Financing interventions of government would have ordinarily been a succor to change the narrative of ugly financial accessibility of SMEs, but, the level of accessibility and its relationship to SMEs have largely been understudied. Hence, this study seeks to examine the deficiencies in the government interventions to SMEs and present a workable financial intervention framework. Both primary and secondary data were used for this study. Primary data were gathered through the administration of questionnaires. Purposive sampling technique was adopted to select 100 registered SMEs in each of the six states of the Southwest Nigeria, while 100 unregistered SMEs were equally selected for inclusiveness totaling 700. The data were analyzed using both descriptive and inferential analytical methods with the aid of SPSS. The study has documented the deficiencies of the previous interventions to include poor design of the programme, favoritism in the disbursement of financing facilities, low level of awareness of the facilities, difficulty in the procedures for accessing government financing support. The study thus proposed a framework where the guarantee scheme is designed into result-based financing where the designated scheme will just give guarantee to the banks to provide loan without collateral and with reduced interest, and a first-time loan which will be jointly financed by the banks and the scheme
\end{abstract}

KEYWORDS: finance, interventions, sustainability, small and medium sized enterprises, debt structure

\section{INTRODUCTION}

In Nigeria, the SME sector is an emerging sector which has a great potential to play an important role in the economic rejuvenation and could potentially enable the Nigerian government reduce 
International Journal of Business and Management Review

Vol.10, No.1, pp.25-43, 2022

Print ISSN: 2052-6393(Print),

Online ISSN: 2052-6407(Online)

its reliance on the oil industry. This is necessary due to the fact that the oil industry is known to be a depletable source of income that is expected to dwindle within the few decades (Sivakumar \& Sarkar 2012; Alrashidi, 2013). Thus, the SME sector deserves more attention and robust policy and programmes that can drive the potentials of the sector to engender strong and diversified economy which can place Nigeria among the ten largest economy in the world by 2030 .

The key issues affecting the SMEs in the country can be grouped into four namely: unfriendly business environment, poor or low accessibility to funding, low managerial skills and lack of access to modern technology (Financial System Strategy 2020 SME Sector Report, 2007). Among these, shortage of finance occupies a very central position. Globally, commercial banks which remain the biggest source of funds to SMEs have in most cases shied away because of the perceived risks and uncertainties, weak financial bases, low credit ratings and poor business structures. Banks are often reluctant to lend money to SMEs as these enterprises lack the necessary credit information required to measure financial solvency, default risk and ascertain the nature and size of the business (Ramady, 2010). Due to the level of risk involved in lending money to SMEs, the interest rates for loans from banks are high (Ramady, 2010, CBN, 2007). Banks find it challenging to cover the high costs of credit associated with lending to SMEs because of the weak capital base, poor financial records of SMEs, and market competition (Adebisi \& Olayinka, 2013; Vasilescu, 2014).

The Nigerian government, having considered the oil price volatility and the need to address its high reliance of its budget on oil, by diversifying the economy, has embarked on a series of programmes and reforms to boost non-oil sector of the economy. In this regard, SMEs have attracted the interest of the government as a viable alternative method to grow the economy and provide the Nigerian government with a strong backup for revenue generation. It was in this regard that Nigerian governments at different periods, introduced a number of financing interventions, to facilitate flow of funds without hindrance to SMEs through specialized banks/agencies such as Bank of Industry, Central Bank of Nigeria or special programmes such as National Enterprise Development Programme, Small and Medium Enterprises Credit Guarantee Scheme (SMECGS), or direct disbursement of fund to the needy, e.g. trader money of the present federal government of Nigeria. Interventions to promote access to finance for Small- and Medium-sized Enterprises (SMEs) constitute an important component of the development strategy of many governments and donors. Despite the government's efforts to enhance and support the bankability of SMEs, these enterprises still struggle to obtain finance in Nigeria and remain un-served or under-served by banks (Rocha et al. 2011a). Given the nature and size of these businesses, banks and other financial institutions are often reluctant to lend them money (Coleman, 2004).

Indeed, it has been shown that SMEs often have difficulties accessing finance, even, the government-sponsored finance, due to the characteristics of the businesses and the owners or managers (Dabo, 2006). In many instances, the interventions are usually designed for SMEs without preliminary studies on the efficacies or otherwise of the programme. Thus, the extent at which those interventions have contributed to SME performance has remained vague in Nigeria. 
International Journal of Business and Management Review

Vol.10, No.1, pp.25-43, 2022

Print ISSN: 2052-6393(Print),

Online ISSN: 2052-6407(Online)

Available studies such as Cravo and Piza (2016) only performed a systematic review on business support services for SMEs, and Grimm and Paffhausen (2015) analyzed the employment effects of interventions targeting micro entrepreneurs and SMEs (they do not assess the effect on other/intermediary outcomes), all with special focus on developed economies. Hence, this study intends to fill this gap by assessing the government financing interventions in Nigeria and SME sustainability. This will reveal the potent and weakness of those interventions and present the framework for usage in future intervention programme.

Financing interventions of government would have ordinarily been a succor to change the narrative of ugly financial accessibility of SMEs, but, the level of accessibility and its relationship to SMEs have largely been understudied. Therefore, the study seeks to embark on assessment of government financing intervention and SMEs sustainability in Nigeria, hoping to actualize the enormous importance of SMEs and have a sustainable finance framework for the industry

\section{REVIEW OF LITERATURE}

\section{Overview of Small Enterprises}

In general, the SME sector falls into three categories: micro, small, and medium enterprises or businesses. There is no universally accepted definition of small businesses due to their global diversity and characteristics. Many countries define small businesses in terms of work force, management structure, and capital investment limit (Lucky \& Olusegun, 2012). In defining small businesses, different countries use certain criteria in terms of size and sector. Countries such as Britain, the United States, and various European countries define small-scale enterprises in terms of turnover and number of employees (Gbandi \& Amissah, 2014).

The definition and classification of small businesses in Nigeria are based on the capital employed, turnover, and number of employees (Gbandi \& Amissah, 2014). One definition of a small business is one that employs fewer than 50 people and has a basic capital value of less than N500,000 (Juliana, 2013). Another definition of a small business propagated by the Central Bank of Nigeria $(\mathrm{CBN})$ describes a small-scale business an enterprise whose total cost, excluding cost of land but including working capital, is above N1.0 million but does not exceed N10.0 million. The Nigerian Industrial Development Bank (NIDB) defined small-scale enterprises as companies with not more than N750,000.00 in project cost (investment and working capital; Juliana, 2013). The National Economic Reconstruction Funds (NERFUND) defined SMSs as an enterprises with fixed assets not including land but inclusive of the cost of new investment not exceeding N10.0 million (Juliana, 2013). In addition, Nigerian industrial policy defines SMEs as industries with total investments of N100, 000 and N2.0 million exclusive of land but including working capital (Lucky \& Olusengu, 2012). Furthermore, the Small and Medium Industries Equity Investment Scheme (SMIEIS) in Nigeria defined SMEs as enterprises with total capital employed of not less than N1.5 million but not above N200 million, including working capital but excluding the cost of land and/or of not less than 10 staff and not exceeding 300 (Sokoto \& Abdullahi, 2013). 
International Journal of Business and Management Review

Vol.10, No.1, pp.25-43, 2022

Print ISSN: 2052-6393(Print),

Online ISSN: 2052-6407(Online)

This study adopts the definition given by CBN, which indicates that small scale enterprises are those with less than N1.0 million in total asset base (excluding real estate) and fewer than 50 full-time employees. Medium enterprises are companies with a total asset base (excluding real estate) and fewer than 50 million and consist of less than 100 full-time workers (Sokoto \& Abdullahi, 2013). The significant role played by SMEs in bringing about social and economic development, as well as income distribution, and poverty alleviation has increased interest in their development among world leaders all over the globe.

Researchers have established three core principles of small businesses. The first is, small business's ability to improve competition and entrepreneurship, thereby increasing aggregate productivity growths. Second, small businesses have more productivity capability than large firms do but experience more institutional failures and lack of development caused by financial market barriers. Third, small businesses have greater ability to create employment than large firms do because they have more labor intensity capability (Sokoto \& Abdullahi, 2013).

\section{Small Business Financing}

Capital plays a vital role in the sustained growth of small businesses (Boateng \& Abdulrahman, 2013). Small businesses have challenges with funding in developing economies that affect their growth and long-term survival. Akinola and Iordoo (2013) using a sample of 100 micro, small, and medium enterprises (MSMEs) in Lagos identified the lack of financial resources as the missing middle between the Nigerian capital markets and the MSMEs. Despite several government initiatives, small businesses still have difficulties in securing loans from microfinance institutions (MFIs) due to the high level of poverty (kanayo et al., 2013). According to Byrd, Ross, and Glackin (2013) the survival of small businesses depends on access to credit.

Capital is a fundamental requirement to succeed in a business enterprise. Some researchers have argued that small businesses are under-capitalized. This undercapitilization is because many entrepreneurs have a tendency to depend on their personal capital or familyes savings to start a business, which is a limited means of capitalization (Okpara, 2011). Samson, Mary, Yemisi, and Erekpitan (2012) suggested that implementing an effective working capital management system helped to increase the profitability of companies. Managing working capital is a managerial accounting strategy, which focuses on sustaining efficient levels of current assets and current liabilities. Samson et al. (2012) contended that working capital management helped companies maintain their cash flow to meet short-term debt obligations and running expenses as well as improving their earnings.

Small-scale businesses have difficulties in obtaining credit facilities from financial institutions due to inadequate collaterals and adequate financial records required by the banks (Okpara, 2011). For example, findings by Boateng et al. (2013) revealed that personal savings and supplier credit ranked as most important sources of capital for small businesses in West Africa, which support previous research findings of Asikhia (2010) and Samson et al. (2012) which proved the importance of personal savings as capital for MSMEs. Firm size, age of the firm, and relationship ownership type positively influenced access to banking in Ghana and Nigeria. 
International Journal of Business and Management Review

Vol.10, No.1, pp.25-43, 2022

Print ISSN: 2052-6393(Print),

Online ISSN: 2052-6407(Online)

Overall, it is important for the government to create an alternative stock exchange, in the Nigerian capital market, dedicated to micro, small and medium enterprises (MSMEs) as practiced in the developed countries. In addition, MSMEs need to prepare suitable financial records in conformity with the expectation of regulators, stakeholders, and financial institutions.

\section{Government intervention in SME Financing}

In an attempt to improve the operational performance of the SMEs and aid their development, the government, post-independence, established various schemes such as Industrial Development Centers (IDCs) in 1962, Small Scale Industries Credit Scheme (SSICS) in 1971, Small Scale Industries Fund (SSIF). The government issued policy initiatives aimed at addressing the peculiar needs of the SMEs through existing commercial banks. Such among others include: the Rural Banking Scheme (1977); National Economic Reconstruction Fund (NERFUND) was established in the mid-1980s to assist SMEs to adjust to the Structural Adjustment Programme. The Fund provided a long term loan support (5-10 years) to SMEs at concessionary interest rates; established the community banking scheme in 1991 with the objective of rural development and providing start-up facilities for smallholders; establishment of Bank of Industry (BOI) with the principal objective of providing credit to the industrial sector including SMEs at an interest rate of 10 percent; the Nigerian Agricultural Cooperative and Rural Development Bank (NACRDB) were also established with the objective of financing the rural sector with particular interest in the SME subsector; the Community Banking Scheme (1992) which gave mandates to commercial banks to provide finance to the SMEs.

These initiatives failed mainly because of political instability, lack of fiscal discipline, inconsistent macroeconomic policies, by the government who established them. Despite the failures of most of the initiatives mentioned above, the need to put in place a policy framework that will help promote the development of a robust SME sector remains ever-present. These issues necessitated the formulation of new policies and attitudes towards the growth and development of SMEs in Nigeria. The schemes include:

\section{Small and Medium Enterprises Equity Investment Scheme (SMEEIS)}

This scheme commenced operation in 2001, under the supervision of the CBN. The objective of this scheme was to facilitate finance and management expertise to small and medium scale industries in Nigeria. Banks were to set aside 10 percent of their Profit after Tax annually in support of equity investment in small and medium enterprises. The arrangement eliminates the interest burden and other associated charges on SME financing. This innovative Scheme affords SMEs access to long-term funding, disciplined approach to business and management as well as the opportunity to integrate into the formal financial sector among others.

\section{Small and Medium Enterprises (SME) Credit Guarantee Scheme (SMECGS)}

The Small and Medium Enterprises (SME) Credit Guarantee Scheme (SMECGS) was introduced in April 2010 to fast-track the development of the manufacturing and SME sub-sector by providing 80.0 percent guarantee for bank credits. The purpose of the intervention is to create more jobs and to provide N100 million maximum loan facility with five (5) years tenor for each project. As at end-September, 2017 the total number of applications guaranteed from inception 
International Journal of Business and Management Review

Vol.10, No.1, pp.25-43, 2022

Print ISSN: 2052-6393(Print),

Online ISSN: 2052-6407(Online)

was 88 (Eighty-eight), valued at N4.251 billion. Also, cumulatively, the total number of fully repaid loans stood at 40 valued N2.228 billion since inception to date.

\section{N200 Billion Refinancing/Restructuring Facilities to Small and Medium Enterprises/Manufacturing (RRF)}

The Scheme was introduced in April 2010 to fast-track the development and revitalisation of ailing SMEs in the country through refinancing and restructuring of Deposit Money banks' (DMBs) existing loan portfolio. The facility has a tenor of 15 years and an annual interest rate of 7.0 percent repayable quarterly. From the inception of the program to end-September, 2017, the cumulative disbursements to clients through the Bank of Industry (BOI) stood at N381.99 billion in respect of 604 projects. Also, a total of N186.542 billion has so far been repaid by the DMBs. A total of 344 projects valued $\$ 85.148$ bn have so far been fully liquidated under the Scheme from inception to date.

\section{Real Sector Support Facility (RSSF)}

The CBN had in November 2014 approved the establishment of an N300 billion Real Sector Support Facility (RSSF) to address the funding needs of large ticket SMEs in Nigeria. It is aimed at closing the short-term and high- interest financing gap for SME/Manufacturing and start-ups, as well as create jobs through the Real Sector of the Nigerian economy. Cumulatively, a total of ten (10) projects valued N35.581bn have so far been disbursed under RSSF. The cumulative repayment by the DMBs to CBN from inception to September 2017 under RSSF is $\$ 357.0 \mathrm{mn}$.

\section{The Micro Small and Medium Enterprises Development Fund (MSMEDF)}

In recognition of the considerable contributions of the Micro, Small and Medium establishments (MSME) subsector to the Nigerian economy and the huge financing gap in the country, the CBN launched the MSME improvement Fund on August 15, 2013, with a share capital of N220 billion. Ten (10) percent of the Fund has been devoted to developmental goals while ninety (90) percent to commercial components to be released to Participating Financial Institutions (PFIs) at $2 \%$ interest rate for on-lending to MSMEs at a maximum of $9 \%$ per annum. Eligible activities to be financed consist of the agricultural value chain, services, cottage industries, artisans, and any income generating business as can be prescribed by the CBN now and then. As at end-August, 2017 the cumulative wholesale amount disbursed stood at N115.178 billion.

\section{N50 Billion Textile Sector Intervention Fund}

The Central Bank of Nigeria in a bid to resuscitate the Textiles Industry has put in place a N50 billion special mechanisms for the restructuring of existing facilities and provision of further facilities for textile companies with a genuine need for intervention. This was the result of the meetings between the Governor and owners of textile mills in Nigeria on August 7, and September 29, 2015. Among the resolutions reached were that the Textile Mills articulate the status of their BOI CTG Loans stating their outstanding loan balances, tenure, interest rate, interest payment and the assistance being sought from CBN. Cumulatively, the sum of N26.386 billion has been disbursed in favour of thirty-one (31) projects from inception to date. 
International Journal of Business and Management Review

Vol.10, No.1, pp.25-43, 2022

Print ISSN: 2052-6393(Print),

Online ISSN: 2052-6407(Online)

\section{Establishment of Entrepreneurship Development Centres (EDCs)}

This initiative was aimed at developing strong SMEs that can complete globally and contribute to national growth and development. Three EDSs were established in Kano, Lagos and Onitsha. Three new EDCs in Maiduguri, Makurdi and Calabar were later established, followed by Kano, Ibadan and Umuahia, and one outreach Centre located in the Minna. Cumulatively from inception, 30,262 participants were trained out of the total target of 28,500. 23,592 jobs were created while 11,809 accessed a total of $\mathrm{N} 2.595 \mathrm{bn}$ as loan to start their businesses.

\section{The Nigerian Industrial Development Bank (NIDB) Ltd}

The primary mandate was to provide medium to long-term loans for investment in industrial activities. Although its loan portfolio covered mainly large-scale industries, the bank had a special unit that focused on SME's financial requirements. An attractive feature of NIDB's financing was its policy of equity participation in some of the projects it financed. It disbursed a total of $\$ 174.6$ million to the SMEs between 1980 and 1988 and was also responsible for the bulk of credit delivery to the SMEs under the SME II loans scheme of the World Bank. It also accounted for more than 80 percent of the total number of disbursements under the scheme. Arising from financial and other constraints, NIDB was merged with similar institutions in 2001 to form the new Bank of Industry (BOI) (Sanusi, 2003).

\section{The Nigerian Bank for Commerce and Industry (NBCI)}

The Federal Government established the NBCI in 1973 in the wake of its indigenisation policy in 1972 to promote the development of small and medium industries in the country. The principal function of the NBCI was the provision of long-term investment financing and equity funds to small and medium industries. The bank also engaged in share underwriting, project identification and feasibility studies. Sources of funds for NBCI included subventions from the Federal Government and the CBN through penalties imposed on commercial and merchant banks for credit shortfalls on loans to small and medium scale enterprises. The NBCI operated as an apex financial institution for the SME and thus, administered the SME I World Bank loan scheme. It approved a total of 797 projects with the project value amounting to 965.5 million between 1973 and 1989 and disbursed $\$ 141.82$ million between 1987 and 1988 (Olorunshola, 2003). The NBCI suffered from operational problems, culminating in a state of insolvency from 1989 and was merged with another programme to form the Bank of Industry.

A major characteristic of all the above schemes is the fact that Government played a very dominant role both as the sole owner of these development finance institutions and a major provider of the financing for the SMEs which explains why the SMEs failed to develop adequately. This is a major deficiency in the functioning of those programmes and the reasons for their unsustainability.

According to Eluhaiwe (2012), the $\$ 200$ billion special intervention funds for small businesses in Nigeria have assisted the SMEs in making unprecedented yearly earnings of $\$ 35.30$ billion since its establishment in 2010. This was made possible due to the relatively cheap loans they accessed from the government intervention fund at single digit interest rate. The government intervention scheme has also generated over 16,422 new jobs, sustained the operations of 347 
International Journal of Business and Management Review

Vol.10, No.1, pp.25-43, 2022

Print ISSN: 2052-6393(Print),

Online ISSN: 2052-6407(Online)

projects and resuscitated more than nine moribund companies, thus, increasing capacity utilisation in companies from a pre-intervention level of 25 percent to 36 percent. Financing SMEs lead to increased revenues and profits of SMEs, thus, increasing government income from taxation.

\section{Empirical Review}

Despite the fact that small businesses constitute $90 \%$ of the overall businesses in Nigeria, they contribute only about $1 \%$ to the GDP. Gbandi and Amissah (2014) investigated the financing of SMEs in Nigeria and various financial options available to them. The focus was on debt financing, and the role played by commercial, microfinance, co-operatives and other financial institutions in the funding of SMEs in Nigeria. In addition, they also considered the role of equity financing through Venture Capital and Business Angels financing. Empirical evidence has established that finance contributes about $25 \%$ to the success of the small businesses.Zairani and Zaima (2013) noted that banks would only give loan to small businesses with a good financial record, collateral, viable business, with a good relationship with the bank, and business expertise in their field. Business Angels provide capital and contribute to their investors capabilities. Moses and Adebisi (2013) investigated the existence and role of small business angels as a source of financial, human, and social capital to overcome challenges of funding for small businesses in Nigeria. They found that Angel financing is a viable alternative source for financing small businesses in Nigeria. Moses and Adebisi (2013) recommended publicizing activities of Angels to support other government programs on small business financing.

On the other hand, Terungwa (2012) used a quantitative method to assess the financing options available to small and medium scale enterprises in Nigeria, using a case study of Benue and Nasarawa states to evaluate the most available option patronized by the SMEs. The findings revealed that SMEs finances come from informal sources rather than the formal sources of finance. Moreover, Kanayo, Jumare, and Nancy (2013) used a quantitative approach to examine the impact on the outreach and sustainability of MFIs in Nigeria, in terms of providing support to the relevant group. Kanayo et al. argued that microenterprise finance could not be financially feasible due to the high interest on small loans and a lack of realizing profits from loans. Credit risks were at the root of bank's reluctance to grant credit to small businesses. In most cases, financial institutions were not willing to take the risk of giving loan facilities to small businesses as opposed to the larger companies. Oliyide (2012) found that inaccessibility to funds from banks contributed to small business inadequate contribution to economic development in Nigeria. Likewise, Oni, Paiko, and Ormin (2012) further provided insight into how small businesses lack of access to finance has formed impediments to their contribution to economic growth and development, which has affected their productivity and ancillary functions. There are inconsistencies on the role of capital in influencing success or failure of a small business in Africa.

Small businesses require enhanced productivity through ample financing in order to maintain or make an appreciable contribution to the socioeconomic development of a country like Nigeria. The risk associated with small businesses make them less desirable for formal sources of finance whose structure is more organized. Terunga (2012) noted that small businesses lacked good risk 
International Journal of Business and Management Review

Vol.10, No.1, pp.25-43, 2022

Print ISSN: 2052-6393(Print),

Online ISSN: 2052-6407(Online)

management strategies and insurance cover that was responsible for their financial problems. Microfinance institutions had collapsed due to poor loan quality, high transaction costs, widespread delinquency, and management deficiencies. Kanayo et al. (2013) recommended savings by microfinance institutions and measures from successful initiatives from other countries such as Indonesia and Bangladesh.

Olusoye (2013) suggested SMEs output proxy by wholesale and retail trade output as a component of gross domestic product, commercial banks' credit to SME and the exchange rate of naira to the United State dollar exert positive influence on economic development, proxy real gross domestic product while lending rate is found to exert negative effects on economic growth. In addition, small business output and commercial banks credit were significant factors contributing to economic growth in Nigeria at 5\% critical level. Olusoye maintained that the Central Bank of Nigeria (CBN) should create an enabling environment for small business development. Microfinance banks have a significant impact on the growth of small businesses while the microfinance policy significantly influences employment opportunities.

\section{RESEARCH METHODOLOGY}

The primary focus of this study is the SMEs sector of the Nigeria economy, as the success of this sector is considered to be of vital importance in the achievement of long-term sustainable economic growth. However, the major focus of this study is the Southwestern Nigeria which comprises Lagos, Oyo, Ogun, Ondo, Ekiti and Osun States. Qualitative data were sourced through the administration of structured questionnaires. For the administration of questionnaires, two sets of respondents were focused which SMEs operators that have obtained finance through government financing interventions within the period under study and those that have never obtained such finance before. These two categories were drawn from both registered SMEs and unregistered ones. List of registered SMEs was obtained from each state ministry of commerce or corresponding ministry under which SMEs are registered and a sample size of 900 operators of SME were randomly selected for questionnaire administration. Also, the unregistered SMEs were equally be selected through purposive sampling technique. Thus, two sets of questionnaires were designed; one for those that have ever obtained finance support through government financing interventions, while the second set of questionnaires will be for those that have never obtained finance through government financing interventions.

The data were analysed using the Statistical Package for the Social Sciences (SPSS). These data were analysed using both descriptive and inferential analytical methods. The descriptive analyses involved the use of percentage table, charts, mean value, chi-square tests etc. while the inferential analysis involved the conduct of correlation tests, regression analysis and analysis of variance to address the hypotheses and meet the objectives of the study 
International Journal of Business and Management Review

Vol.10, No.1, pp.25-43, 2022

Print ISSN: 2052-6393(Print),

Online ISSN: 2052-6407(Online)

\section{FINDINGS}

Descriptive approach involving the administration of 900 copies of questionnaires was conducted in two major axes of the south-west Nigeria, which includes Osun/Oyo axis and Lagos/Ogun axis. A total of 700 copies of questionnaire representing $78 \%$ of the total questionnaires administered were retrieved from the field and hence the analysis was based on the copies of questionnaire retrieved.

\section{Social Demographic Characteristics of the Respondents}

From Table 1, demographic and personal data of the respondents as shown by gender revealed that $520(74.3 \%)$ of respondents were male, while $180(25.7 \%)$ were female. This shows that male respondents participated more in the study than female respondents. This signifies that male is more into SME than female. Demographic data for age also shows that $45(6.4 \%)$ of the respondents were below ages of 20 years, 150(21.4\%) were in the age group of 21-30 years, $310(44.3 \%)$ were between the ages of 31-40 years, 132(18.9\%) were between the ages of 41-50 years, 63(9.0\%) were 51 above years of age. The age that participated more in the survey fall between 31-40 years. Profile of respondents by marital status shows that $113(16.1 \%)$ of the respondent surveyed were single, while 552 (78.9\%) surveyed were married by implication most respondents were married. Demographic and personal data of the respondents for educational qualification of respondents also shows that $1(2 \%)$ respondents possessed the School Leaving Certificate, 55(7.9\%) possessed the WASSCE/SSCE/GCE, 205(29.3\%) of respondents possessed the Ordinary National Diploma (OND/DIP), 390 (55.7\%) had the Bachelor's degree and Higher National Diploma, 50(7.1\%) were MPA/MBA/M.A/M.Sc, it could be inferred that majority of the respondents that participated in this research are Bachelor's degree and Higher National Diploma. Collated data of respondents by state also revealed that 294(42.0\%) of the respondent surveyed had racial background of Osun/Oyo state, while 406 (58.0\%) surveyed had racial background of Lagos/Ogun State which revealed that more people were from Lagos/Ogun State. Demographic data of respondents of years spent before start up business also shows that 338 $(48 \%)$ of the respondents were 2years or less, $282(40 \%)$ were between the group of 3-5 years, while 50(7.1\%) were between the group of 6-10 years, 25(3.6\%) were more than 10 years and $5(0.7 \%)$ were not applicable. The implications therefore is that the respondents surveyed were appropriately distributed and possess the capacity to make informed decision about government activities, especially, regarding the financing intervention of the government. 
Print ISSN: 2052-6393(Print), Online ISSN: 2052-6407(Online)

Table 1: DEMOGRAPHICAL IMFORMATION

\begin{tabular}{|c|c|c|c|}
\hline Items & Variables & Frequency & Percentage \\
\hline \multirow[t]{3}{*}{ Sex } & Male & 520 & 74.3 \\
\hline & Female & 180 & 25.7 \\
\hline & Total & 700 & 100 \\
\hline \multirow[t]{6}{*}{ Age } & below 20years & 45 & 6.4 \\
\hline & 21-30years & 150 & 21.4 \\
\hline & 31-40years & 310 & 44.3 \\
\hline & 41-50years & 132 & 18.9 \\
\hline & 51 years \& above & 63 & 9.0 \\
\hline & Total & 700 & 100 \\
\hline \multirow[t]{4}{*}{ Marital Status } & Single & 113 & 16.1 \\
\hline & Married & 552 & 78.9 \\
\hline & Divorce & 35 & 5 \\
\hline & Total & 700 & 100 \\
\hline \multirow[t]{5}{*}{ Educational Background } & WASSCE/SSCE/GCE & 55 & 7.9 \\
\hline & OND/DIP & 205 & 29.3 \\
\hline & B.Sc/HND & 390 & 55.7 \\
\hline & MPA/MBA/M.A/M.Sc. & 50 & 7.1 \\
\hline & Total & 700 & 100 \\
\hline \multirow[t]{3}{*}{ Racial background } & Osun/Oyo State & 294 & 42.0 \\
\hline & Lagos/Ogun State & 406 & 58.0 \\
\hline & Total & 700 & 100 \\
\hline \multirow[t]{6}{*}{$\begin{array}{l}\text { Year of working before start } \\
\text { up business }\end{array}$} & 2 years or less & 338 & 48 \\
\hline & $3-5$ years & 282 & 40 \\
\hline & $6-10$ years & 50 & 7.1 \\
\hline & More than 10 years & 25 & 3.6 \\
\hline & Not Applicable & 5 & 0.7 \\
\hline & Total & 700 & 100 \\
\hline
\end{tabular}

Source: Field Survey 2021

Motivation for Assessing Financial Initiatives Intervention

Although, the government plan for introducing SME financing interventions was to engender growth and development in the economy through the promotion of SME subsector. However, varying factors have motivated the SMES operators to access the interventions. The Table 2 below shows that 385 (55\%) were motivated by the need to expand their business. This is actually for those that have been in business before and therefore requires funding for the expansion of their business. In the same vein $11.9 \%$ of the respondent were motivated by the need to sustain and remain in business. This category of respondents only wants to remain in business regardless of the economic situations. About 15\% of the respondent indicated that they only access the financing interventions in order to establish a new venture. This category of respondents, under normal circumstances, are supposed to be more targeted so as to increase the 
SMEs base in the economy. Also, about $17 \%$ of the respondents were moved by the need to increase their business coverage. This implies that this category of respondent has been in business for a while, and only need to increase the business coverage by increasing its customer base. Also, less than $1 \%$ of the respondent indicate that the need to test or confirm the true position or validity of the intervention were the reasons for accessing the financial interventions. From this result, it can be established that, while the main motive of introducing financial intervention were to encourage the establishment of new venture and promote sustainability of those already in business, the major respondent and those that actually access the fund more were those that needed the funding for the expansion and not necessarily those that wanted a new venture or remain in business. Therefore, future intervention should be designed in such a way as to give more credence to those intending to establish a new venture or those that have suffered from the economic downturn occasioned by the recent health pandemic. The result therefore shows that majority of the surveyed respondents are already engaging in one economic activity or the other and their major business needs is expansion. With this knowledge, the future financing intervention of the government should be designed in such a way to promote expansion more.

Table 2: Motivation for Assessing Financial Initiatives Intervention

\begin{tabular}{|l|l|}
\hline Variables & Frequency \\
\hline The need for expansion & $385(55.0)$ \\
\hline The need to sustain and remain in business & $83(11.86)$ \\
\hline The need to establish a new venture & $105(15.0)$ \\
\hline The need to increase the business coverage & $122(17.43)$ \\
\hline The need to test or confirm of the facilities & $5(0.71)$ \\
\hline Total & $700(100)$ \\
\hline
\end{tabular}

Source: Field work 2021

percentage values in parenthesis

\section{Reasons for not assessing any of the government financing schemes}

As good as the motive for the government financial interventions were, there were a number of reasons that discouraged some people from accessing the intervention. Among those reasons include politicization of the financing facilities $(18 \%)$. This category of people believe that the financing skill were political in nature and has been politicized and therefore they could not access it. Another category of people indicated that there are unaware of the facilities. This category represents $21 \%$ of the total respondent. This perhaps could be as a result of the low level of awareness creation by the government or that the awareness was created for the elite and not those that were not educated. Also, another category of respondent which represent $17 \%$ of the total respondent attributed the reasons for not accessing the scheme to the favoritism that characterized the disbursement of the facilities. This shows that in the implementation of the scheme, there were some levels of favoritism which could not be divorced from many government programs. In the same vein, about $12 \%$ of the respondent alluded the reason for not accessing the government financing to the lack of peer information about the application process. Others indicated the reason such as inclusion of interest rate, need for collateral etc. The result 
Print ISSN: 2052-6393(Print), Online ISSN: 2052-6407(Online)

therefore shows that the main factor for not accessing government financing intervention include, low level of awareness of the people about the program, politicization of the financing scheme, and high level of favoritism that characterize the disbursement of the intervention scheme.

Table 3: Reasons for not assessing any of the government financing schemes

\begin{tabular}{|l|l|}
\hline Variables & Frequency \\
\hline Inclusion of (high) interest rate & $78(11.14)$ \\
\hline Favoritism in the disbursement of financing facilities & $122(17.43)$ \\
\hline Politicization of the financing facilities & $127(18.14)$ \\
\hline Unaware of the facilities & $149(21.29$ \\
\hline Lack of collateral & $123(17.57)$ \\
\hline Lack of clear information on the application process & $86(12.29)$ \\
\hline $\begin{array}{l}\text { The government financing scheme does not favour } \\
\text { SMEs }\end{array}$ & $15(2.14)$ \\
\hline Total & $700(100)$ \\
\hline
\end{tabular}

Source: Field work 2021

percentage values in parenthesis

A further analysis and breakdown of the reasons for not accessing the intervention funds can be established by considering the demographical distribution of the responses of the respondents. From the Table below, it can be established that majority of surveyed respondents

Table 4: If you have not assessed any of the government financing schemes before, what were the reasons?

\begin{tabular}{|l|l|l|l|l|}
\hline \multirow{2}{*}{ Variables } & \multicolumn{2}{l|}{ Racial background } & \multirow{2}{*}{ Total } \\
\cline { 2 - 5 } & $\begin{array}{l}\text { Osun/Oyo } \\
\text { State }\end{array}$ & $\begin{array}{l}\text { Lagos/Ogun } \\
\text { State }\end{array}$ & $\begin{array}{l}\text { Ondo/Ekiti } \\
\text { State }\end{array}$ & Total \\
\hline Inclusion of (high) interest rate & $30(4.3)$ & $37(5.3)$ & $6(1)$ & $73(10.4)$ \\
\hline Favoritism in the disbursement of financing facilities & $47(6.7)$ & $71(10.1)$ & $4(1)$ & $122(17.4)$ \\
\hline Politicization of the financing facilities & $27(3.9)$ & $99(14.1)$ & 1 & $127(18.1)$ \\
\hline Unaware of the facilities & $59(8.4)$ & $89(12.7)$ & 2 & $150(21.4)$ \\
\hline Lack of collateral & $67(9.6)$ & $55(7.0)$ & 1 & $123(17.6)$ \\
\hline Lack of clear information on the application process & $34(4.9)$ & $50(7.1)$ & 2 & $86(12.3)$ \\
\hline The government financing scheme does not favour SMEs & $12(1.7)$ & 3 & 4 & $19(2.7)$ \\
\hline Total & $\mathbf{2 7 6}$ & $\mathbf{4 0 4}$ & $\mathbf{2 0}$ & $\mathbf{7 0 0}$ \\
\hline
\end{tabular}

Source: Field work 2021 
International Journal of Business and Management Review

Vol.10, No.1, pp.25-43, 2022

Print ISSN: 2052-6393(Print),

Online ISSN: 2052-6407(Online)

\section{Development of Sustainable Framework for Government Financing Interventions}

Desktop review of extant literature and various publications/document of government interventions to SME sustainability shows that, various government of Nigeria have over the years introduced a number of measures geared towards promoting SMEs sustainability in Nigeria. This section begins by examining the fall out of the various interventions in the past and the causes of those fall outs. Thereafter, the study presents a workable approach for sustaining SMEs in the country.

\section{Some of the financing challenges they encounter include:}

- Accessibility to sustainable funds has perennially constituted a hindrance to adequate funding of Small and Medium Enterprises (SMEs), leading to the premature collapse of these industries.

- Majority of the SMEs do not keep records for fear of tax obligations. The prevailing corrupt tendency in Nigeria, which has permeated the fabric of the society including Nigeria entrepreneurs, has prevented most small and medium enterprises operators from keeping adequate records. This makes it difficult to translate general policy framework into efficient and sustainable intervention programmes for the benefit of the SMEs in the country.

- Most SMEs operators prefer to get the funds as a loan rather than an equity contribution. They are averse to going into partnership schemes with banks under the SMIEIS programme, thus, setting back most SMEs in the country.

- A good number of SMEs in Nigeria are not aware of the existence of the different sources of funds for SME development; the incentives available for them, as well as how to source funds from banks.

- The poor governance structure is another factor preventing the small and medium enterprises from accessing funds easily from banks and other specialised financial institution.

\section{Framework for Sustainable Government Financial Interventions}

The findings of this study have revealed that a number of issues about government financial intervention which serve as guide to future development and design of another intervention programme. It has been established that what usually drive people to government intervention scheme include are many and include the need for expansion, the need to sustain and remain in business, the need to establish a new venture, the need to increase the business coverage, the need to test or confirm of the facilities. It has equally been established that among the various reasons that usually put potential applicants off the interventions include inclusion of (high) interest rate, favoritism in the disbursement of financing facilities, politicization of the financing facilities, unaware of the facilities, lack of clear information on the application process, and the government financing scheme does not favour SMEs.

The study has equally documented the deficiencies of the previous interventions to include poor design of the program in addressing the needs of the SMEs, government financing is only favorable to already grown business and not new business, it is not well publicized for the people to be aware of it, the finance being provided is not sufficient for business expansion, it requires very stressful procedures: Difficulty in the procedures for accessing government financing support. 
International Journal of Business and Management Review

Vol.10, No.1, pp.25-43, 2022

Print ISSN: 2052-6393(Print),

Online ISSN: 2052-6407(Online)

Summing all the above findings together, it can be established that most of the previous interventions are both structurally deficient and economically unguided. Structurally, the design and procedures are not well tailored towards a specific economic structure, it used to be generalized, that is, making the same scheme available to many economic structures without a regard to the individual characteristics of the would-be applicants. Also, structurally, the linkage usually established to engage potential beneficiaries were usually made so general with giving attention to the peculiarity of individual or group expertise. Economically, the funding was either inadequate or could not reach the targeted beneficiaries due to politics, corruption and favoritism. Therefore, a sustainable platform is such that addresses all these myriad of deficiencies.

It could therefore be established that most of those programmes are either politically motivated or not structurally designed to specifically address the needs of SME sector of the economy. There is usually no specific regulations guiding workings of those programmes and no check put in place to address maladministration. Therefore, to mitigate risks associated with lending to SMEs, this study proposes the establishment of the Credit Guarantee Scheme (CGS) by the government. In particular, Japan is one of the early CGS innovators (Yoshino \& TaghizadehHesary, 2016). After the introduction of the Japanese CGS in 1937, they spread throughout Europe and the Americas in the 1950s and then to Africa, Asia, and Oceania in the 1960s and 1970s (Yoshino \& Taghizadeh-Hesary 2016).

It has been observed that despite the highly 'liquid' nature of banks in Nigeria after the adoption of the liberalization policy, commercial banks still find it difficult to lend to the manufacturing sector including SMEs. The banks claim not to have been able to balance the risk and cost associated with lending to manufacturers (Obokoh, Akinlo \& Goldman, 2015). They perceive the idea of lending to the sector as high risk because of the difficulty of obtaining information on the true financial conditions and performance of firms. The sector was mostly affected by the information asymmetry of the banks is the SMEs sector because of their small capital base. SMEs are often small in nature and this constitutes an obstacle to their access to long-term capital and even access to short-term finance. As a result of their small size, access to finance whether formal or informal is normally at a very high rate of interest and unfavorable conditions (Colombo, Croce \& Guerini, 2012). It has been stated that the SME sector is usually neglected and discriminated against in terms of access to finance, management and marketing expertise, government support and new technology, as compared to large enterprises in many developing countries (Bhavani, 2006). This has been particularly so in economies in transition, where the large-scale sector had assumed the major role in economic and industrial development (Kinda \& Loening, 2010).

\section{The Proposed Framework}

Having identified the inadequacies of the various interventions and considering the various strategies adopted in various countries such as Saudi Arabia, Qatar, Malaysia, Canada etc, this study therefore proposes a front-end intervention scheme. The intervention scheme proposed can be domiciled in a department/unit under the CBN management but with regulation also from the 
ministry of finance. There should be a classification of audience into Manufacturing, Service, Informal, and there should be criteria such as turnover and size of employees. The guarantee scheme should be designed into result-based financing where the designated scheme will just give guarantee to the banks to provide loan without collateral and with reduced interest, and a first-time loan which will be jointly financed by the banks and the scheme.

The workings of this proposed framework is simply represented in the following diagram:

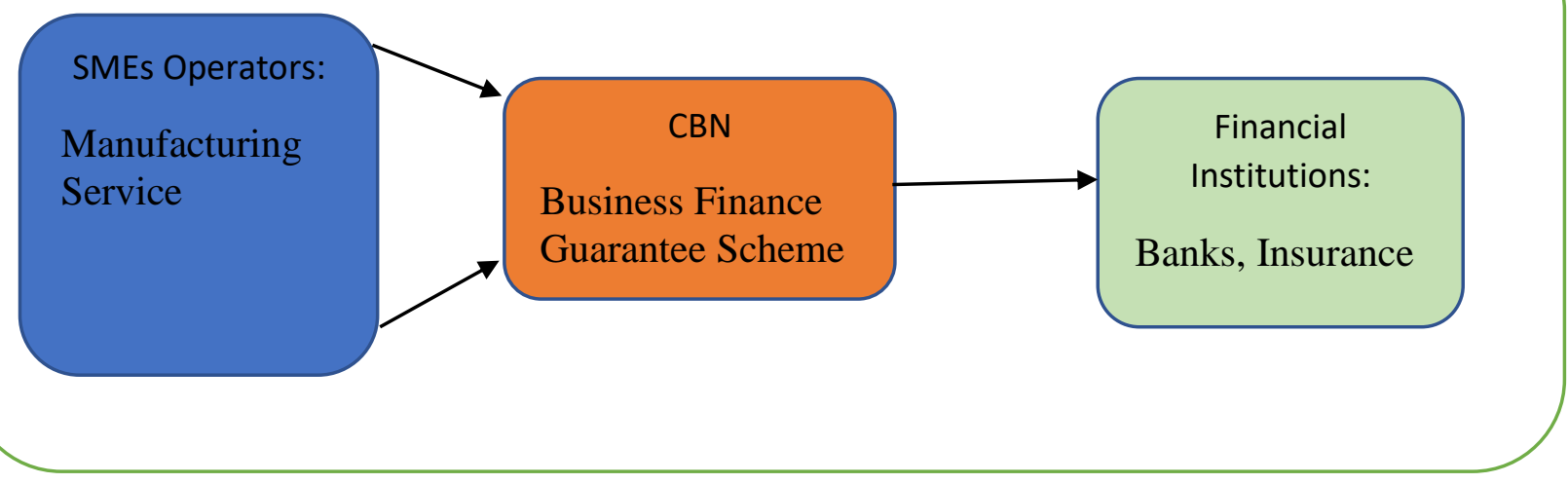

Figure 1: Credit Guarantee Scheme Framework

The SME operators represent the demand side of the framework while financial institutions represent the supplier of the fund. In between these two parties is the Central Bank of Nigeria that acts as mediator and financier. The SME operators approach the Unit in the Central Bank, specially designed for attending to the needs of the SME operators. This Unit/section, which should be established in each of the State capitals of the federation, will then look at the proposal submitted by the concerned SME operator for proper scrutiny. This special Unit will first check to identify the main need of the proposal. The needs could be training, motivation, connection, or fund. Then, the applicant can, if the required fund is between a particular threshold that the Unit itself can offer, then, it does. If otherwise, that the required fund is significantly huge, then, the applicant can first be invited for discussion with experts in the chosen area, thereafter, be directed to a specific commercial bank for fund which will be guaranteed by the $\mathrm{CBN}$ and low/no interest rate.

Financing for SMEs in the appropriate forms is important at all stages of the business life cycle, in order to enable these firms to start up, develop and grow, and make contributions to employment, growth and social inclusion. Access to finance improves post-entry performance of start-ups and industries which are more dependent on external finance grow relatively faster in countries with more developed financial markets, thanks to enhanced information sharing and risk management, and a better allocation of resources to profitable investment projects. On the other hand, financing constraints that prevent firms from investing in innovative projects, seizing growth opportunities, or undertaking restructuring in case of distress negatively affect 
International Journal of Business and Management Review

Vol.10, No.1, pp.25-43, 2022

Print ISSN: 2052-6393(Print),

Online ISSN: 2052-6407(Online)

productivity, employment, innovation and income gaps. (Giovannini, Mayer, Micossi, Di Noia, Onado, Pagano, \& Polo 2015).

\section{SUMMARY, CONCLUSION AND RECOMMENDATION}

The broad objective of this study is to assess the government financing interventions in relation to SMEs sustainability. The study revealed that the SME operators needed government intervention because of the need for expansion, need to sustain and remain in business, need to establish a new venture, the need to increase the business coverage, government intervention scheme include are many and include. It has equally been established that among the various reasons that usually put potential applicants off the interventions include inclusion of (high) interest rate, favoritism in the disbursement of financing facilities, politicization of the financing facilities, unaware of the facilities, lack of clear information on the application process, and the government financing scheme does not favour SMEs. The study has equally documented the deficiencies of the previous interventions to include poor design of the program in addressing the needs of the SMEs, government financing is only favorable to already grown business and not new business, it is not well publicized for the people to be aware of it, the finance being provided is not sufficient for business expansion, and it requires very stressful procedures: difficulty in the procedures for accessing government financing support. The study proposed a unified credit guarantee scheme as a sustainable strategy of addressing financial needs of SMEs and engender desirable development in Nigeria.

This study has thus established that government has recognized the need for a comprehensive and integrated framework with sustainable systems, capable of addressing the problems of SMEs and promoting a virile SME sub-sector and as such has established several SME-oriented programmes and activities. Government should put in place measures to enhance the availability of finance to SMEs, particularly in the area of institutional credit that would provide affordable medium and long-term loans for expansion and working capital needs. Government should establish Credit Guarantee and Insurance Schemes to address the problem of SMEs providing collaterals to banks before loans are administered to the sub-sector.

\section{Referencing}

Ademola, I. S., \& Michael, A. A. (2012). Small scale businesses as a remedy to unemployment problem in Nigeria. International Journal of Scientific \& Engineering Research, 3(11), 16.

Akinola, A. O., \& Iordoo, D. A. (2013). Effects of the Nigerian capital market on the micro, small and medium scale enterprises (MSMEs) in Nigeria. Research of Journal of Finance and Accounting, 4(7), 1-14.

Alberto, G., Colin, M., Micossi, S., Di Noia, C., Marco, O., Marco, P., \& Polo, A. (2015).

Restarting European Long-Term Investment Finance: A Green Paper Discussion Document.

Alrashidi, F. (2013). Comparison of the performance of Islamic mutual funds vs. ethical and conventional mutual funds (Doctoral dissertation, Durham University). 
International Journal of Business and Management Review

Vol.10, No.1, pp.25-43, 2022

Print ISSN: 2052-6393(Print),

Online ISSN: 2052-6407(Online)

Aremu, M. A., \& Adeyemi, S. L. (2011). Small and medium scale enterprises as a survival strategy for employment generation in Nigeria. Journal of sustainable development, 4(1), 200.

Baptista, R., \& Preto, M. T. (2011). New firm formation and employment growth: regional and business dynamics. Small Business Economics, 36(4), 419-442.

Bartelsman, E., Haltiwanger, J., \& Scarpetta, S. (2009). 1. Measuring and Analyzing CrossCountry Differences in Firm Dynamics. In Producer dynamics (pp. 15-80). University of Chicago Press.

Bello, B., \& Ivanov, S. (2014). growth strategies for very small organizations: a case study of a very small entrepreneurship. International Journal of Organizational Innovation, 6(4).

Bloom, N., Mahajan, A., McKenzie, D., \& Roberts, J. (2010). Why do firms in developing countries have low productivity?. American Economic Review, 100(2), 619-23.

Boateng, A., \& Abdulrahman, M. D. (2013). Micro small-sized enterprises and bank credit: evidence from West Africa. Journal of emerging market finance, 12(2), 129-150.

Byrd, K., Ross, L., \& Glackin, C. (2013). A preliminary causal analysis of small business access to credit during economic expansion and contraction. Journal of Applied Finance \& Banking, 3(5), 77-84.

Coleman, S. (2004). The charismatic gift. Journal of the Royal Anthropological Institute, 10(2), 421-442.

Cravo, T., \& Piza, C. (2016). The impact of business support services for small and medium enterprises on firm performance in low-and middle-income countries: a meta-analysis. World Bank Policy Research Working Paper, (7664).

Dabo, D. A. (2006). Financing of small and medium sized enterprises in Nigeria (Doctoral dissertation, (C) Danjuma Adamu Dabo).

Etim, E. O. (2010). promoting small and medium scale enterprises in Nigeria: a panacea for realization of financial systems strategy (FSS) 2020. International Journal of Economic Development Research and Investment, 1(2), 3.

Gbandi, E. C., \& Amissah, G. (2014). Financing options for small and medium enterprises (SMEs) in Nigeria. European Scientific Journal January.

Gupta, S., Modgil, S., \& Gunasekaran, A. (2020). Big data in lean six sigma: a review and further research directions. International Journal of Production Research, 58(3), 947969.

Grimm, M., \& Paffhausen, A. L. (2015). Do interventions targeted at micro-entrepreneurs and small and medium-sized firms create jobs? A systematic review of the evidence for low and middle income countries. Labour Economics, 32, 67-85.

Kanayo, O., Jumare, F., \& Nancy, S. (2013). Challenges of microfinance access in Nigeria: Implications for entrepreneurship development. Mediterranean Journal of Social Sciences, 4(6), 611-611.

Malchow-Møller, N., Schjerning, B., \& Sørensen, A. (2011). Entrepreneurship, job creation and Wage growth. Small Business Economics, 36(1), 15-32.

Moses, O., \& Adebisi, J. F. (2013). Small business financing in Nigeria: An investigation of the angel option. Canadian Social Science, 9(2), 93-98.

Ojeka, S. (2011). Tax policy and the growth of SMEs: Implications for the Nigerian economy. Research Journal of Finance and Accounting, 2(2). 
International Journal of Business and Management Review

Vol.10, No.1, pp.25-43, 2022

Print ISSN: 2052-6393(Print),

Online ISSN: 2052-6407(Online)

Okpara, J. O. (2011). Factors constraining the growth and survival of SMEs in Nigeria: Implications for poverty alleviation. Management research review.

Olutunla, G. T., \& Obamuyi, T. M. (2008). An empirical analysis of factors associated with the profitability of Small and medium-enterprises in Nigeria. African Journal of business management, 2(11), 195-200.

Peltier, J. W., \& Naidu, G. M. (2012). Social networks across the SME organizational lifecycle. Journal of Small Business and Enterprise Development.

Ramady, M. A. (2010). The Saudi Arabian economy: Policies, achievements, and challenges. Springer Science \& Business Media.

Sivakumar, A. D., \& Sarkar, S. (2012). women entrepreneurs in small and medium scale businesses in Saudi Arabia. International Journal Of Finance \& Policy Analysis, 4(1).

Sokoto, A. A., \& Abdullahi, Y. Z. (2013). Strengthening small and medium enterprises (SMEs) as a strategy for poverty reduction in North Western Nigeria. American Journal of Humanities and Social Sciences, 1(3), 189-201.

Stein, P., Ardic, O. P., \& Hommes, M. (2013). Closing the credit gap for formal and informal micro, small, and medium enterprises.

Terungwa, A. (2012). Financing options available to small and medium scale enterprises (SMEs) in Nigeria: a critique. The Business \& Management Review, 3(1), 278.

Vasilescu, L. (2014). Accessing finance for innovative EU SMEs key drivers and challenges. Economic Review: Journal of Economics and Business, 12(2), 35-47. 